\title{
Distribusi dan Pemetaan Varian-Varian Bahasa Selayar di Kabupaten Sumbawa dan Sumbawa Barat
}

\section{Oleh}

\author{
Fatma Astifaijah*)
}

\begin{abstract}
Abstrak
Bahasa merupakan alat komunikasi yang paling ampuh untuk menyatakan identitas suatu kelompok masyarakat. Dengan bahasa, kita dapat memperkuat kepribadian bangsa, mempertebal rasa harga diri, dan sebagai alat kebanggaan nasional serta kesatuan nasional.

Di wilayah Nusa Tenggara Barat, bahasa yang digunakan secara garis besar ada empat bahasa yaitu bahasa Bali, bahasa Sasak, bahasa Sumbawa, dan bahasa Bima. Di samping itu ada bahasa lain seperti bahasa Jawa, bahasa Bugis, bahasa Selayar, dan bahasa Sunda yang jumlah pemakainya tidak sebesar empat bahasa tersebut. Salah satu bahasa yang dijadikan sebagai bahan penelitian adalah bahasa Selayar. Bahasa Selayar merupakan salah satu variasi dialek dari bahasa Makasar. Bahasa Selayar di Provinsi Nusa Tenggara Barat hanya ada di daerah pesisir pantai Sumbawa Barat dan Sumbawa Besar.
\end{abstract}

Kata kunci: varian-varian bahasa, dialektometri, dan kantong bahasa (enklave)

\section{Pengantar}

Usaha pelestarian, pembinaan dan pengembangan bahasa daerah memerlukan berbagai informasi kebahasaan yang lengkap dengan melakukan penelitian. Melalui penelitian dapat diperoleh dan dikumpulkan berbagai informasi dan data kebahasaan bahasa daerah yang dapat digunakan untuk pembinaan dan pengembangan bahasa, pengembangan sastra dan pengembangan sosial budaya pada umumnya sekaligus menunjang pembangunan nasional dan pembangunan sumber daya manusia Indonesia. Selain itu, usaha-usaha pembinaan,

\footnotetext{
*) Sarjana Pendidikan, Pembantu Pimpinan pada Kantor Bahasa Prov. NTB
} 
pengembangan bahasa daerah juga mencakup kegiatan-kegiatan inventarisasi bahasa daerah dengan jalan pemetaan bahasa.

Daerah Nusa Tenggara Barat memiliki luas daerah $17.700 \mathrm{~km}$. Secara administratif Provinsi Nusa Tenggara Barat terbagi atas enam kabupaten dan dua kota, yaitu Kota Mataram, Kabupaten Lombok Barat, Kabupaten Lombok Tengah, Kabupaten Lombok Timur--keempat wilayah ini terdapat di Pulau Lombok, sedangkan Kabupaten Sumbawa Barat, Kabupaten Sumbawa, Kabupaten Dompu, Kota Bima, dan Kabupaten Bima terdapat di wilayah Pulau Sumbawa.

Dilihat dari letak geografisnya, Provinsi Nusa Tenggara Barat merupakan wilayah lintas budaya dan lintas agama sehingga secara tidak langsung bahasa yang ada di wilayah ini bermacam ragam bahasa daerah yang masing-masing memiliki aturan-aturan/kaidah-kaidah yang berbeda-beda dan mungkin pula ada persamaan-persamaan yang terdapat di dalamnya.

Adanya berbagai macam ragam bahasa yang ada di wilayah Nusa Tenggara Barat perlu dilestarikan dengan jalan melakukan penelitian pemetaan bahasa. Salah satu bahasa yang dijadikan sebagai bahan penelitian adalah bahasa Selayar. Bahasa Selayar merupakan salah satu variasi dialek dari bahasa Makasar.

Menurut informasi bahasa Selayar di Provinsi Nusa Tenggara Barat hanya ada di daerah pesisir pantai Sumbawa Barat dan Sumbawa Basar. Meskipun pada dasarnya kita ketahui bahwa keseluruhan wilayah NTB adalah laut, khusus di wilayah Labuhan Mapin, penggunaan bahasa Selayar digunakan sebagai alat komunikasi bagi tiga kelompok etnis yang ada di wilayah tersebut. Ketiga kelompok etnis itu adalah etnis Bajo, etnis Bugis, dan etnis Selayar. Penelitian bahasa Selayar di wilayah NTB belum pernah dilakukan sama sekali. Hal ini menjadi alasan 
perlunya bahasa Selayar untuk dijadikan sebagai bahan penelitian pemetaan bahasa.

Berdasarkan latar belakang di atas, jelaslah bahwa permasalahan dalam penelitian ini dapat dirumuskan sebagai berikut (1) Ada berapakah varian bahasa Selayar di Kabupaten Sumbawa dan Kabupaten Sumbawa Barat?; (2) Bagaimanakah hubungan kekerabatan antarvarian bahasa Selayar di Kabupaten Sumbawa dan Kabupaten Sumbawa Barat?; (3) Berapakah jumlah penutur bahasa Selayar di Kabupaten Sumbawa dan Kabupaten Sumbawa Barat?; (4) Di manakah sebaran geografis bahasa Selayar di Kabupaten Sumbawa dan Kabupaten Sumbawa Barat?

Adapun hasil penelitian ini diharapkan dapat bermanfaat untuk menyediakan deskripsi tentang pola hubungan kekerabatan antarvarian bahasa Selayar, jumlah variannya, jumlah penuturnya dan sebaran geografisnya di Kabupaten Sumbawa dan Kabupaten Sumbawa Barat. Di samping sebagai upaya penentuan, pembinaan dan pengembangan bahasa itu sendiri terutama dalam penentuan skala prioritas bahasa mana yang akan dibina dan dikembangkan dalam masyarakat tutur sehingga bisa menjadi acuan untuk penelitian lanjutan, pembinaan, dokumentasi, dan inventarisasi data dan aset-aset kebahasaan secara nasional.

Penelitian dialektologi yang menitikberatkan pada pemetaan atau geografis wilayah pemakai bahasa-bahasa nusantara pertama kali dilakukan oleh Esser (1938) kemudian diteruskan oleh Wurm dan Hattori (1983).

Mbete (1990) untuk disertasi di Universitas Indonesia, dan sekaligus membantah penelitian Dyen (1978) yang menunjukkan hubungan keasalan tripilah(tripartite) antara ketiga bahasa tersebut.

Penelitian dalam bidang dialek geografis yang mengambil objek bahasa Sumbawa, yaitu: (a) dilakukan Sukarta dkk. (1985) dengan judul 
Geografi Dialek Bahasa Sumbawa di Pulau Sumbawa dan (b) dilakukan oleh Herusantoso dkk. (1987) dengan judul Pemetaan Bahasa-Bahasa di Nusa Tenggara Barat. Kedua penelitian tersebut sama-sama dilakukan oleh Tim peneliti dari Universitas Udayana, Denpasar, Bali.

Adapun penelitian lain yang mencoba melihat bahasa dalam hubungannya dengan geografi pemakaian bahasa adalah penelitian yang dilakukan oleh Mahsun (1994) dengan judul Penelitian Dialek Geografi Bahasa Samawa; Burhanuddin (2004) dengan judul Enkalve Samawa di Pulau Lombok Kajian Linguistik Diakronis; Burhanuddin, dkk (2005) dengan judul Kontak Bahasa antara Bahasa Sasak dengan Samawa di Lombok Timur; dan I Nyoman Sudika, dkk. dengan judul Bahasa Samawa dan Bahasa Bali di Pulau Lombok.

Berdasarkan pemaparan di atas, belum dijumpai satu penelitian pun yang mencoba melihat bahasa Selayar di Sumbawa, khususnya menggunakan pendekatan dialektologi diakronis.

Penelitian ini merupakan kajian variasi dialektal, maka teori yang digunakan adalah teori dialektologi diakronis (periksa Mahsun, 1995). Menurut teori ini, kajian dialektologi meliputi dua aspek, yaitu aspek deskriptif dan aspek historis yang dialami oleh suatu bahasa.

Walaupun dialektologi diakronis pada dasarnya mencakup dua aspek, penelitian ini akan lebih banyak difokuskan pada aspek deskriptif. Sehubungan dengan itu, aspek historis yang akan dikaji hanya sampai pada tahap penentuan hubungan kekerabatan antarvarian bahasa Selayar di Kabupaten Sumbawa dan Kabupaten Sumbawa Barat.

Sehubungan dengan deskripsi perbedaan unsur-unsur kebahasan patut dijelaskan perbedaan konseptual antara perbedaan bidang fonologi dan leksikon. Pada dasarnya, perbedaan yang mendasar antara bentukbentuk yang dikategorikan sebagai bentuk yang berbeda secara fonologis 
dengan yang berbeda secara leksikal terletak pada dapat/tidaknya bentukbentuk yang berbeda itu dihubungkan pada sebuah bentuk purba yang sama. Apabila bentuk-bentuk yang berbeda itu dapat dihubungkan pada sebuah bentuk bahasa purba yang sama, bentuk-bentuk yang berbeda itu dikategorikan berbeda secara fonologis. Sebaliknya jika bentuk-bentuk yang berbeda itu tidak dapat dihubungkan pada sebuah bentuk asal yang sama, perbedan itu terjadi pada level leksikal.

Patut ditambahkan bahwa perbedaan pada level fonologi ini mencakup perbedaan yang bersifat teratur atau dan perbedaan yang bersifat sporadis (tidak teratur) atau yang disebut variasi. Termasuk ke dalam perbedaan yang bersifat teratur ini adalah apa yang disebut sebagai sangat sempurna, sempurna, dan kurang sempurna.

Perbedaan itu disebut sangat sempurna apabila perbedaan yang disebabkan oleh perubahan bunyi itu terjadi pada semua data yang disyarati oleh kaidah perubahan serta sebaran geografisnya sama, sedangkan perbedaan yang berupa sempurna juga terjadi pada semua data yang disyarati oleh kaidah perubahan, tetapi sebaran geografis antarcontoh yang satu dengan contoh yang lainnya tidak sama. Adapun perbedaan disebut kurang sempurna jika perubahan bunyi itu terjadi pada 2--5 buah contoh dengan sebaran geografisnya sama; dan perbedaan disebut variasi, jika kaidah perubahan bunyi itu hanya terjadi pada sebuah atau dua buah contoh dengan sebaran geografis yang berbeda. Perbedaan yang berupa variasi ini dapat berupa, antara lain metatesis, asimilasi, disimilasi, apokope, sinkope, aferesis, kontraksi dll. (bandingkan Mahsun, 1995 dengan Crowley, 1987 dan Lehmann, 1973).

Dalam kajian geografi dialek, peta bahasa merupakan hal yang mutlak diperlukan. Tiap tanyaan dengan data yang diperoleh melalui tanyaan itu dari semua daerah pengamatan yang diteliti akan dipetakan. 
Peta-peta itu, dari bahan-bahan yang terkumpul dari setiap daerah pengamatan, akan menampakkan semua gejala kebahasaan (Ayatrohaedi, 1985:58).

Lebih lanjut Mahsun (1995:58) menyatakan bahwa ada dua jenis peta yang digunakan dalam dialektologi, yaitu peta peragaan (display map) dan peta penafsiran (interpretatif map). Penelitian ini menggunakan peta peragaan yang berisi tabulasi data lapangan dengan tujuan agar datadata itu tergambar di antara daerah pengamatan, sedangkan peta penafsiran yang memuat akumulasi pernyataan-pernyataan umum tentang distribusi perbedaan unsur-unsur linguistik yang dihasilkan, yang dibuat sebagai telaah lanjutan untuk hal-hal khusus, yang berkaitan dengan inovasi dan relik, tidak digunakan dalam penelitian ini.

Aspek historis dalam penelitian ini hanya berusaha mengelompokkan isolek-isolek bahasa Selayar yang ada di Kabupaten Sumbawa dan Kabupaten Sumbawa Barat.

Metode yang digunakan adalah metode cakap dengan teknik cakap semuka, teknik catat dan teknik rekam. Instrumen yang digunakan sebagai pedoman wawancara adalah instrumen berupa daftar tanyaan yang sudah ditetapkan oleh Pusat Bahasa, yaitu berisi 200 kosakata swadesh, 880 kosakata budaya dasar. Akan tetapi instrumen dianalisis hanya 400 kosakata dasar data yang berisi kosakata dasar swadesh, kosakata budaya dasar bagian tubuh, sistem kekerabatan, gerak dan kerja, dan kata tugas karena analisis fonologi dan leksikon dianggap representatif menjawab permasalahan yang dirumuskan.

Informan yang akan diambil pada setiap daerah pengamatan adalah sebanyak tiga orang. Dari tiga orang tersebut, satu orang ditentukan sebagai informan utama, sedangkan dua orang informan lainnya dijadikan sebagai informan pendamping. 
Dalam pemilihan informan digunakan kriteria-kriteria sebagai berikut: (a) berjenis kelamin pria atau wanita, (b) berusia antara 25--65 tahun (tidak pikun), (c) orang tua, isteri atau suami yang berdomisili di desa/dusun itu minimal 10 tahun, (d) berpendidikan minimal tamat pendidikan dasar (SD--SLTP), (e) dapat berbahasa Indonesia, dan (f) sehat jasmani dan rohani, dalam arti, sehat jasmani adalah tidak cacat berbahasa dan memiliki pendengaran yang tajam untuk menangkap pertanyaan-pertanyaan dengan tepat; sedangkan sehat rohani maksudnya tidak gila atau pikun (bandingkan Mahsun, 1995 dengan Nothofer, 1981).

Desa-desa yang dijadikan sampel dipilih berdasarkan kriteria jarak antardesa, tingkat heterogenitas, dan ciri-ciri desa. Tingkat heterogenitas maksudnya bahwa satu lokasi harus terkomposisi atas penduduk yang berlatar belakang asal yang berbeda, seperti dari Selayar Makasar, Selayar Bira, Selayar Bugis, dan Selayar Bajo. Jarak antardesa maksudnya, bahwa jarak desa-desa yang dipilih sebagai satuan pengamatan satu sama lain minimal $\pm 20 \mathrm{~km}$.

Untuk jelasnya, desa-desa yang dipilih sebagai satuan pengamatan dapat dilihat pada peta berikut ini.

\section{Peta Lokasi Daerah Pengamatan Bahasa Selayar di Kabupaten Sumbawa dan Sumbawa Barat}




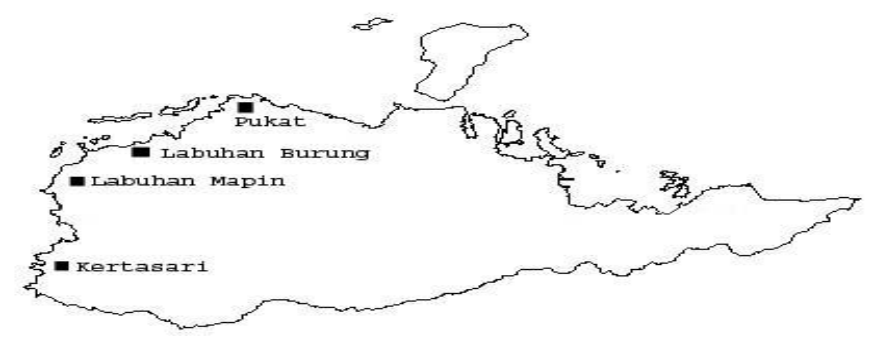

\section{Peta 1}

Masing-masing daerah pengamatan akan peneliti kunjungi 3 hari berturut-turut disebabkan jarak antarlokasi cukup berjauhan dan untuk kepentingan akurasi dan kelengkapan data yang dihasilkan.

Tahap berikutnya data yang diperoleh dianalisis yang berkaitan dengan analisis penentuan unsur-unsur bahasa yang berbeda dilakukan dengan cara melihat bentuk-bentuk yang menjadi realisasi dari suatu makna tertentu pada setiap daerah pengamatan, pemetaan unsur-unsur bahasa yang berbeda tersebut ditemukan dari hasil analisis di atas yang secara metodologis dapat dilakukan dengan menggunakan sistem lambang, petak, dan langsung. Namun, dalam pelaksanaan penelitian ini hanya digunakan pemetaan dengan sistem lambang dan petak, dan penentuan dialek bahasa Selayar dianalisis berdasarkan penentuan isolek sebagai bahasa, dialek, atau subdialek dilakukan dengan menggunakan dua pendekatan. Pendekatan pertama adalah pendekatan kuantitatif dititikberatkan pada penggunaan metode dialektometri.

Adapun pendekatan secara kualitatif dititikberatkan pada penggunaan metode timbal balik (mutual intelligibility), metode berkas isoglos (Bunddle of Isoglosses). 
Selain menggunakan metode-metode di atas, peneliti juga menggunakan metode yang bersifat kualitatif, yaitu metode inovasi bersama yang bersifat ekslusif (exslusively shared innovation atau exslusively shared of linguistics features). Metode ini dimaksud sebagai cara pengelompokan bahasa turunan ke dalam suatu kelompok yang lebih dekat hubungannya karena memperlihatkan inovasi yang berciri linguistik ekslusif yang menyebar pada bahasa-bahasa yang diperbandingkan (Mahsun, 2005). Metode ini lebih dapat dipertanggungjawabkan, lebih-lebih jika bahasa yang diperbandingkan yang memperlihatkan inovasi bersama itu berjauhan letak sehingga kesamaan inovasi yang secara ekslusif muncul itu bukan sebagai hasil pinjaman atau pengaruh mempengaruhi satu sama lain.

Metode inovasi bersama ini dapat juga diterapkan pada penentuan hubungan kedekatan antardialek yang ada dalam satu bahasa. Hanya saja, bedanya bukti pengelompokan yang digunakan adalah bukti dialektal, bukan bukti bahasa seperti yang digunakan dalam penelitian linguistik historis komparatif.

\section{Pembahasan}

\subsection{Pembahasan}

\subsubsection{Deskripsi Perbedaan Linguistik dan Daerah Sebaran.}

Berdasarkan data yang terkumpul telah teridentifikasi sebanyak 266 buah peta perbedaan unsur-unsur kebahasaan yang meliputi kedua bidang di atas.

\subsubsection{Perbedaan Fonologi}

\subsection{Korespondensi Vokal}

Korespondensi vokal yang ditemukan dalam penelitian ini ada 9 buah. Dengan rincian korespondensi vokal sempurna 3 buah dan 
korespondensi vokal kurang sempurna 6 buah. Untuk lebih jelasnya akan diberikan contoh di bawah ini.

Korespondensi Sempurna antara $\supset-\supset \cong 0-0$, misalnya:

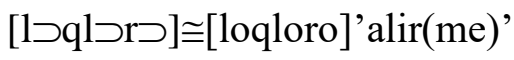

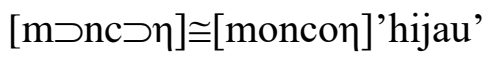

$$
\begin{aligned}
& {[\mathrm{t} \supset \mathrm{b} \supset \mathrm{q}] \cong[\text { toboq]'tikam(me)' }}
\end{aligned}
$$

Daerah sebaran korespondensi vokal sempurna ini adalah: bentuk [つ-つ] pada daerah pengamatan: 1,2 dan bentuk [o-o] pada daerah pengamatan 3,4 .

[s $\supset \mathrm{qm} \supset \mathrm{q}] \cong[$ soqmoq] 'gemuk,lemak'

[bつd $\supset] \cong[$ bodo] 'pendek'

Daerah sebaran korespondensi vokal sempurna ini adalah: bentuk [つ-つ] pada daerah pengamatan: 3,4 dan bentuk [o-o] pada daerah pengamatan 1,2 Kemudian ada beberapa makna yang daerah sebarannya tidak sama, yaitu makna 'dorong' digunakan bentuk [s $\supset \mathrm{r} \supset \eta]$ pada daerah pengamatan 1 dan bentuk [soron] pada daerah pengamatan 2,3,4.

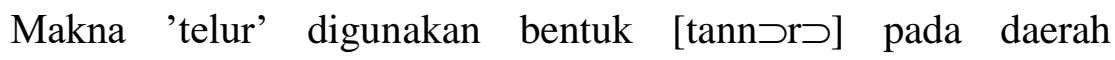
pengamatan 2 dan bentuk [tannoro] pada daerah pengamatan 1,3,4.

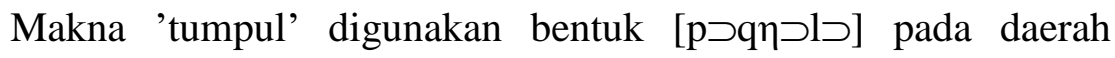
pengamatan 4 dan bentuk [poqnolo] pada daerah pengamatan 1,2,3.

\subsection{Korespondensi Konsonan}

Korespondensi konsonan yang ditemukan dalam penelitian ini ada 6 buah. Dengan rincian korespondensi konsonan sangat sempurna 1 buah; korespondensi konsonan sempurna 2 buah; dan korespondensi konsonan kurang sempurna 3 buah.

Untuk lebih jelasnya akan diberikan contoh di bawah ini.

Korespondensi Sangat Sempurna antara $b \cong h / \#$-, misalnya: 
Kantor Bahasa Provinsi NTB

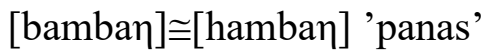

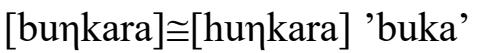

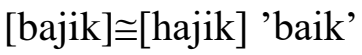

Daerah sebaran korespondensi konsonan sangat sempurna ini adalah: bentuk [b] pada daerah pengamatan: 1,2 dan bentuk [h] pada daerah pengamatan 3,4. Untuk makna 'baik' digunakan pula bentuk [ballo] pada daerah pengamatan 2 .

\subsection{Variasi Vokal}

Perbedaan yang berupa variasi vokal yang ditemukan dalam penelitian ini ada 36 buah. Adapun bentuk variasinya dicontohkan sebagai berikut.

Variasi Vokal a Ø/-(K)\#

Daerah sebaran variasi vokal ini adalah:

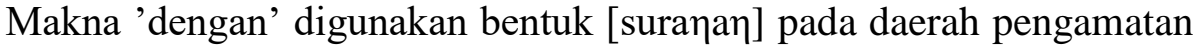
2 dan bentuk [s(i)ura $]$ pada daerah pengamatan 1,3,4 .

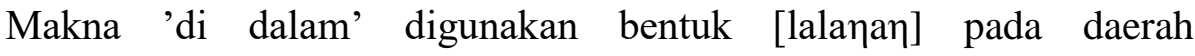
pengamatan 1,2 dan bentuk [lalaך] digunakan pada daerah pengamatan 3,4 .

\subsection{Variasi Konsonan}

Perbedaan yang berupa variasi konsonan yang ditemukan dalam penelitian ini ada 39 buah. Adapun bentuk variasi konsonan dicontohkan sebagai berikut.

Variasi Konsonan $\mathrm{r} \sim$ Ø/-V\#

Daerah sebaran variasi konsonan ini adalah:

Makna 'baru' digunakan bentuk [beru] pada daerah pengamatan 3,4 dan bentuk [bau] pada daerah pengamatan 1,2.

Makna 'cuci' digunakan bentuk [bissri] pada daerah pengamatan 1,2 dan bentuk [bissai] digunakan pada daerah pengamatan 3,4 . 


\subsubsection{Perbedaan Leksikon}

Berdasarkan data yang diperoleh dari penelitian ini, ternyata perbedaan linguistik cukup banyak ditemukan dalam bidang leksikon, disamping perbedaan fonologi dengan daerah sebarannya yang sangat beragam. Untuk lebih jelasnya berikut ini akan dicontohkan secara jelas perbedaan tersebut.

1. Makna 'air' memunculkan dua varian, yaitu bentuk [jeqne] yang digunakan pada daerah pengamatan 1,2 dan bentuk [ere] yang digunakan pada daerah pengamatan 3,4.

2. Makna 'belah (me)' memunculkan dua varian, yaitu bentuk [bissaq] yang digunakan pada daerah pengamatan 1,2,3 dan bentuk [puch] yang digunakan pada daerah pengamatan 4 .

3. Makna 'cacing' memunculkan dua varian, yaitu bentuk [assi] yang digunakan pada daerah pengamatan 1,2 dan bentuk [dagiๆ] yang digunakan pada daerah pengamatan 3,4.

\subsubsection{Penentuan Isolek Sebagai Dialek dan Subdialek}

Dari hasil penghitungan dengan menggunakan metode dialektometri, diperoleh jumlah persentase hubungan kekerabatan antardaerah pengamatan sebagai berikut.

\begin{tabular}{|c|c|c|c|}
\hline No. & Daerah Pengamatan & Persentase $(\%)$ & Kriteria \\
\hline 1. & $1-2$ & 57,14 & Perbedaan Dialek \\
\hline 2. & $1-3$ & 76,32 & Perbedaan Dialek \\
\hline 3. & $1-4$ & 83,08 & Perbedaan Bahasa \\
\hline 4. & $2-3$ & 78,20 & Perbedaan Dialek \\
\hline 5. & $2-4$ & 85,34 & Perbedaan Bahasa \\
\hline 6. & $3-4$ & 27,08 & Perbedaan Wicara \\
\hline
\end{tabular}

Berdasarkan hasil penghitungan secara kuantitatif dengan menggunakan metode dialektometri di atas diperoleh gambaran sementara bahwa daerah-daerah isolek Bahasa Selayar di Kabupaten Sumbawa dan Kabupaten Sumbawa Barat terpilah dalam 3 dialek, yaitu 
(1) Dialek Selayar Kertasari (DSK) dengan daerah pengamatan Desa Kertasari, (2) Dialek Labuhan Mapin (DSLM) dengan daerah pengamatan Desa Labuhan Mapin dan (3) Dialek Selayar Labuhan Burung Pukat (DSLBP) meliputi daerah pengamatan Desa Labuhan Burung dan Desa Pukat.

Dari pernyataan itu, perlu dicari bukti kualitatif yang menyatukan daerah pengamatan 1 dan 4 , dan daerah pengamatan 2 dan 4 untuk menyangkal bahwa daerah tersebut bukan merupakan beda bahasa, melainkan satu bahasa yang merupakan beda dialek. Adapun bukti kualitatif yang ada pada daerah pengamatan 1 dan 4, yaitu terdapatnya korespondensi vokal 7 buah yang terdiri atas korespondensi vokal sempurna 3 buah dan korespondensi kurang sempurna 4 buah dengan jumlah glos sebanyak 10 buah. Korespondensi konsonan 3 buah yang terdiri atas korespondensi sempurna 1 buah dan korespondensi kurang sempurna 2 buah dengan jumlah 9 glos. Variasi vokal 7 buah dan variasi konsonan 4 buah dengan jumlah glos keseluruhan 11 buah. Leksikon kosakata dasar dan kosakata budaya 19 glos. Bukti kualitatif yang menyatukan daerah pengamatan 2 dan 4 , yaitu terdapatnya korespondensi vokal 7 buah yang terdiri atas korespondensi vokal sempurna 3 buah dan korespondensi kurang sempurna 4 buah dengan jumlah glos sebanyak 10 buah. Korespondensi konsonan 2 buah yang terdiri atas korespondensi konsonan sempurna 1 buah dan korespondensi konsonan kurang sempurna 1 buah dengan jumlah 10 glos. Variasi vokal 4 buah dan variasi konsonan 9 buah dengan jumlah glos keseluruhan 13 buah. Leksikon kosakata dasar dan kosakata budaya 17 glos.

Selain melalui analisis dialektometri untuk menentukan dialek/subdialek di atas, juga digunakan analisis berkas isoglos. Berkas isoglos ini digunakan untuk menguatkan penentuan dialek dengan 
memperhatikan garis-garis yang menyatukan daerah-daerah pengamatan yang menggunakan gejala kebahasaan yang sama.

Dengan memperhatikan garis-garis isoglos, dapat dikatakan bahwa terdapat garis-garis yang secara ketat membagi daerah-daerah isolek bahasa Selayar di Kabupaten Sumbawa dan Sumbawa Barat ke dalam 3 dialek, yaitu dialek Selayar Kertasari (DSK), dialek Selayar Labuhan Mapin (DSLM), dan dialek Selayar Labuhan Burung Pukat (DSLBP).

Metode selanjutnya yang diterapkan untuk menguatkan kesimpulan metode di atas adalah Metode Inovasi Bersama yang Bersifat Ekslusif. Penggunaan metode dalam penelitian ini dimaksudkan untuk menemukan data-data kualitatif yang menyatukan atau yang mengisolasi daerah atau daerah-daerah pengamatan ke dalam isolek tertentu. Berdasarkan penerapan metode ini diperoleh data-data sebagai berikut.

1. Data-data kualitatif yang menyatakan daerah pengamatan 1 berada dalam satu dialek tersendiri terdapat pada 7 buah korespondensi vokal yang terdiri atas 3 buah korespondensi sempurna dan 4 buah korespondensi kurang sempurna; 5 buah korespondensi konsonan yang terdiri atas 2 buah korespondensi sempurna dan 3 buah korespondensi kurang sempurna; 32 buah variasi yang terdiri atas 16 buah variasi vokal dan 16 buah variasi konsonan; dan 43 buah leksikon.

2. Data-data kualitatif yang menyatakan daerah pengamatan 2 berada dalam satu dialek tersendiri terdapat pada 9 buah korespondensi vokal yang terdiri atas 3 buah korespondensi sempurna dan 6 buah korespondensi kurang sempurna; 5 buah korespondensi konsonan yang terdiri atas 2 buah korespondensi sempurna dan 3 buah korespondensi kurang sempurna; 35 buah variasi yang terdiri atas 16 
buah variasi vokal dan 19 buah variasi konsonan; dan 50 buah leksikon.

3. Data-data kualitatif yang menyatakan daerah pengamatan 3 dan 4 berada dalam satu dialek tersendiri terdapat pada 7 buah korespondensi vokal yang terdiri atas 3 buah korespondensi sempurna dan 4 buah korespondensi kurang sempurna; 6 buah korespondensi konsonan yang terdiri atas 1 buah korespondensi sangat sempurna, 2 buah korespondensi sempurna dan 3 buah korespondensi kurang sempurna; 53 buah variasi yang terdiri atas 30 buah variasi vokal dan 23 buah variasi konsonan; dan 90 buah leksikon.

Dilihat dari uraian di atas, diperoleh gambaran bahwa bahasa Selayar di Kabupaten Sumbawa dan Sumbawa Barat terbagi dalam 3 dialek, yaitu dialek Selayar Kertasari (DSK) yang penuturnya menyebar di Desa Kertasari, Kecamatan Taliwang, Kabupaten Sumbawa Barat sebagai daerah pengamatan 1; dialek Selayar Labuhan Mapin (DSLM) yang penuturnya menyebar di Desa Labuhan Mapin, Kecamatan Alas Barat, Kabupaten Sumbawa sebagai daerah pengamatan 2; dan dialek Selayar Labuhan Burung Pukat (DSLBP) yang penuturnya menyebar di Desa Labuhan Burung, Kecamatan Buer dan Desa Pukat Kecamatan Utan, Kabupaten Sumbawa, yaitu meliputi daerah pengamatan 3 dan 4.

\subsubsection{Hubungan Kekerabatan Dialek-dialek Selayar}

Hasil perhitungan yang telah digambarkan pada bagian sebelumnya menunjukkan bahwa dialek Selayar di Kabupaten Sumbawa dan Sumbawa Barat terdapat 3 dialek yang memiliki hubungan kekerabatan. Adapun hubungan kekerabatan yang dimaksud di sini hanya ditentukan pada tingkat tinggi atau rendahnya persentase. Daerah pengamatan mempunyai hubungan kekerabatan lebih dekat apabila 
persentase yang dihasilkan rendah, sebaliknya mempunyai hubungan kekerabatan jauh apabila presentase yang dihasilkan tinggi.

Berdasarkan hasil analisis pada bagian terdahulu, dapat ditentukan hubungan di antara ketiganya. Dialek Selayar Kertasari Labuhan Mapin (DSKLM) daerah pengamatan 1 dan 2 berasal dari satu dialek. Hal ini dibuktikan dengan adanya data kualitatif yang menyatukan daerah pengamatan 1 dan 2 . Data kualitatif tersebut adalah 8 korespondensi vokal yang terdiri 3 korespondensi sempurna dan 5 korespondensi kurang sempurna; 6 korespondensi konsonan yang terdiri atas 1 korespondensi sangat sempurna, 2 korespondensi sempurna dan 3 korespondensi kurang sempurna; 16 variasi vokal; 20 variasi konsonan; dan 60 leksikon. Akan tetapi, dalam perkembangannya dialek ini mengalami perubahan sehingga membentuk 2 dialek yang berbeda. Hal ini terbukti adanya beberapa glos yang memisahkan kedua daerah pengamatan tersebut.

Untuk membuktikan perbedaan itu berikut ini akan dipaparkan beberapa bukti kualitatif daerah pengamatan 1 sebagai dialek tersendiri, yaitu adanya 7 korespondensi vokal yang terdiri atas 3 korespondensi sempurna dan 4 korespondensi kurang sempurna; 5 korespondensi konsonan yang terdiri atas 2 korespondensi sempurna dan 3 korespondensi kurang sempurna; 16 variasi vokal; 16 variasi konsonan; dan 43 leksikon. Bukti kualitatif daerah pengamatan 2 sebagai dialek tersendiri, yaitu adanya 9 korespondensi vokal yang terdiri atas 3 korespondensi sempurna dan 6 korespondensi kurang sempurna; 5 korespondensi konsonan yang terdiri atas 2 korespondensi sempurna dan 3 korespondensi kurang sempurna; 16 variasi vokal; 19 variasi konsonan; dan 50 leksikon. 
Selain dengan mencari bukti kualitatif yang telah dipaparkan di atas, kedekatan hubungan daerah pengamatan 1 dan 2 ini dapat pula kita lihat dengan membandingkan daerah pengamatan 3 dan 4 dialek Selayar Labuhan Burung Pukat (DSLBP) dengan menggunakan persentase perbedaan berikut ini.

Daerah pengamatan 1 dan 2 mempunyai sekitar 57,14\% yang dinyatakan beda. Untuk daerah pengamatan 1 dengan 3 dan daerah pengamatan 1 dengan 4 , terdapat masing-masing 76,32\% dan 83,08\% yang berbeda. Dari masing-masing perbedaan tersebut dijumlahkan dan diambil rata-rata ditemukan sekitar 79,7\%. Adapun daerah pengamatan 2 dengan 3 dan daerah pengamatan 2 dengan 4, terdapat perbedaan masingmasing 78,20\% dan 85,34\%. Masing-masing perbedaan tersebut dijumlahkan dan diambil rata-rata ditemukan sekitar 81,77\%. Dari hasil perhitungan di atas, jelas daerah pengamatan 1 (DSK) dan daerah pengamatan 2 (DSLM) mempunyai hubungan kedekatan lebih tinggi dibandingkan dengan daerah pengamatan 3, 4 (DSLBP).

Selanjutnya untuk memperkuat dugaan bahwa memang DSLBP merupakan dialek yang berdiri sendiri berikut ini akan dipaparkan bukti kualitataif. Bukti kualitatif ini memberikan gambaran bahwa DSK dengan DSLBP dan DSLM dengan DSLBP merupakan dialek yang berbeda tetapi berasal dari satu bahasa. Hal ini ditunjukkan dengan terdapatnya beberapa glos yang menyatukan daerah pengamatan 1, 3, 4 dan 2, 3, 4 .

Berikut ini akan dipaparkan bukti kualitatif daerah pengamatan 1,3,4 yaitu terdapat 5 korespondensi vokal yang terdiri atas 2 korespondensi sempurna dan 3 korespondensi kurang sempurna; 3 korespondensi konsonan yang terdiri atas 2 korespondensi sempurna dan 1 korespondensi kurang sempurna; 7 variasi vokal; 3 variasi konsonan; 
dan 11 leksikon. Sedangkan bukti kualitataif daerah pengamatan 2,3,4 yaitu terdapat 7 korespondensi vokal yang terdiri atas 3 korespondensi sempurna dan 4 korespondensi kurang sempurna; 2 korespondensi konsonan yang terdiri atas 1 korespondensi sempurna dan 1 korespondensi kurang sempurna; 4 variasi vokal; 7 variasi konsonan; dan 10 leksikon.

Adapun pohon kekerabatan dialek-dialek bahasa Selayar yang ada di daerah Kabupaten Sumbawa dan Sumbawa Barat, dapat dilihat di bawah ini.

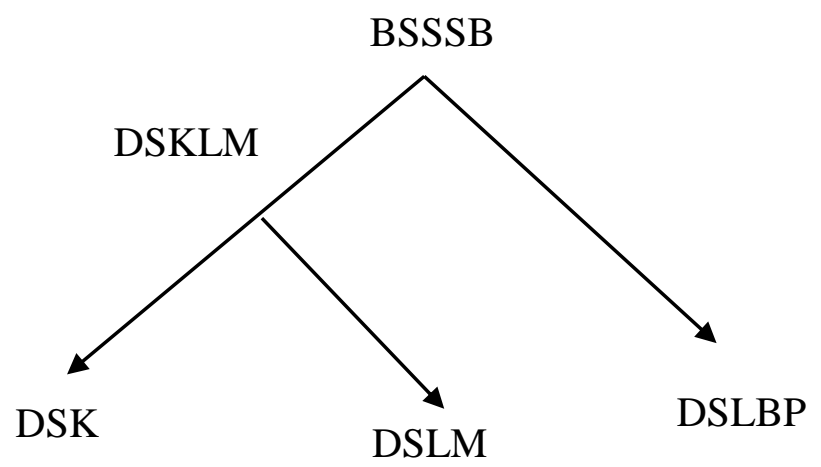

Dari pohon kekerabatan yang digambarkan di atas, menunjukkan bahwa terdapat dua gelombang kedatangan orang Selayar ke wilayah Sumbawa dan Sumbawa Barat. Gelombang pertama kedatangan orang Selayar berada di wilayah Sumbawa Barat dan Sumbawa dengan membentuk dialek Selayar Kertasari Labuhan Mapin (DSKLM). Dengan adanya perbedaan geografis dan masyarakat penuturnya mengakibatkan terpecahnya dialek ini menjadi dua dalam perkembangannya. Adapun dialek tersebut menjadi dialek Selayar Kertasari dan dialek Selayar Labuhan Mapin.

Selanjutnya gelombang kedua kedatangan orang Selayar mengarah pada wilayah Sumbawa tepatnya pada daerah Labuhan Burung dan Pukat. Pada dua daerah ini dialek yang terbentuk menjadi dialek Selayar Labuhan Burung Pukat (DSLBP). 


\subsubsection{Jumlah Penutur Bahasa Selayar}

Berdasarkan Hasil Sensus Penduduk tahun 2000, jumlah penutur bahasa Selayar di Kabupaten Sumbawa Barat sekitar 1.500 orang, sedangkan di Kabupaten Sumbawa sekitar 3.700 orang. Apabila dibandingkan jumlah penutur di dua kabupaten tersebut, memperlihatkan bahwa penutur bahasa Selayar di Kabupaten Sumbawa lebih banyak dibandingkan dengan jumlah penutur di Kabupaten Sumbawa Barat.

Hal ini disebabkan adanya faktor geografis yang mempengaruhi jumlah penduduk. Kabupaten Sumbawa Barat merupakan pecahan dari Kabupaten Sumbawa. Penutur bahasa Selayar hanya menyebar pada satu kecamatan, yaitu Kecamatan Taliwang tetapi menyebar pada dua desa, yaitu Desa Dalam dan Desa Kertasari. Di Kabupaten Sumbawa Bahasa Selayar menyebar pada beberapa kecamatan yang ada di kabupaten ini. Kecamatan itu antara lain Kecamatan Alas Barat, Buer, dan Utan dengan beberapa desa yang ada di kecamatan itu.

\section{Penutup}

\subsection{Simpulan}

Sehubungan dengan uraian di atas akan dikemukakan beberapa hal sebagai hasil kesimpulan dari penelitian distribusi dan pemetaan varian-varian bahasa Selayar di Kabupaten Sumbawa dan Sumbawa Barat. Penelitian Bahasa Selayar ini dilakukan pada 4 daerah pengamatan, yaitu Desa Kertasari Kecamatan Taliwang Kabupaten Sumbawa Barat, sedangkan Desa Labuhan Mapin Kecamatan Alas Barat, Desa Labuhan Burung Kecamatan Buer, dan Desa Pukat Kecamatan Utan di mana ketiga desa ini berada di Kabupaten Sumbawa.

Secara sinkronis, pengelompokan daerah-daerah pengamatan yang bertetangga ke dalam daerah dialek atau subdialek didasarkan pada 
dua pendekatan, yaitu pendekatan kuantitatif yang dalam hal ini menggunakan motode dialektometri dan metode berkas isoglos. Kemudian pendekatan dengan menggunakan evidensi kualitatif yang mencakup penggunaan metode pemahaman timbal balik (mutual intelligibility) dan Metode Inovasi Bersama yang Bersifat Ekslusif.

Hasil perhitungan yang dilakukan secara dialektometri diperoleh 266 buah peta perbedaan unsur kebahasaan dari segi fonologi dan leksikon. Dengan bukti kuantitatif daerah pengamatan 1, 2, dan 3 merupakan daerah satu bahasa, tetapi beda dialek. Daerah pengamatan 4 merupakan daerah beda bahasa apabila diperbandingkan dengan daerah pengamatan 1 dan 2, sedangkan daerah pengamatan 4 merupakan daerah beda wicara apabila diperbandingkan dengan daerah pengamatan 3 . DSLBP bukan merupakan daerah beda bahasa, melainkan satu bahasa dengan dibuktikan adanya beberapa glos yang menyatukan penggunaan bahasa yang sama antara DSK dengan DSLBP dan DSLM dengan DSLBP.

Dari analisis tersebut terungkap bahwa Bahasa Selayar di Kabupaten Sumbawa dan Sumbawa Barat terbagi ke dalam tiga dialek, yaitu dialek Selayar Kertasari (DSK), dialek Selayar Labuhan Mapin (DSLM), dan dialek Selayar Labuhan Burung Pukat (DSLBP).

Hubungan kekerabatan daerah pengamatan 1 (DSK) lebih dekat hubungannya dengan daerah pengamatan 2 (DSLM). Begitu pula sebaliknya bila diperbandingkan dengan daerah pengamatan 3 dan 4 (DSLBP). Dapat dikatakan bahwa daerah pengamatan 1 dan 2 berasal dari satu dialek, tetapi dalam perkembangannya membentuk dua dialek, sedangkan daerah pengamatan 3 dan 4 merupakan dialek yang berdiri sendiri.

\subsection{Saran}


Kantor Bahasa Provinsi NTB

Penelitian tentang distribusi dan pemetaan varian-varian bahasa Selayar di Kabupaten Sumbawa dan Sumbawa Barat perlu dilakukan untuk memberikan gambaran mengenai situasi kebahasaan khususnya di Provinsi NTB dan pada umumnya di Indonesia.

Sehubungan dengan hal di atas, perlu penelitian lebih lanjut sebagai hasil usaha untuk memperjelas dan memperlengkap bahan pemetaan bahasa-bahasa yang ada di wilayah NTB. 


\section{DAFTAR PUSTAKA}

Ayatrohaedi. 2002. "Penelitian Dialektologi”. Jakarta: Pusat Bahasa.Departemen Pendidikan Nasinal.

Bawa, I Wayan. 1983. "Bahasa Bali di Bali: Sebuah Analisis Geografi Dialek”. Jakarta: Universitas Indonesia (Disertasi Doktor).

Danie, J. Akun. 1990. Kajian Geografi Dialek di Minahasa Timur Laut. Jakarta: Balai Pustaka.

Depdikbud. 1993. Tatabahasa Baku Bahasa Indonesia. Jakarta: Depdikbud.

. 1995. Kamus Besar Bahasa Indonesia. Jakarta: Depdikbud

Grijn, C.D. 1991. Kajian Bahasa Melayu-Betawi. Jakarta: PT Pustaka Utama Grafiti.

Herusantoso, Suparman dkk. 1987.'Pemetaan Bahasa-bahasa di Nusa Tenggara Barat". Jakarta: Pusat Pembinaan dan Pengembangan Bahasa.

Hudson, A.B. 1970. “A.Note on Selako: Malayic Dayak and Land Dayak Languages in Western Boeneo". Dalam Serawak Museum Journal, 18: $310-318$

Kridalaksana, Harimurti. 1984. Kamus Linguistik. Jakarta: PT Gramedia Mahsun. 1994. "Penelitian Dialek Geografis Bahasa Sumbawa". Yogyakarta: Universitas Gadjah Mada (Desertasi Doktor).

Dialektologi Diakronis: Sebuah Pengantar. Yogyakarta: Gajah Mada University Press.

. Metode Penelitian Bahasa: Tahapan Strategi, Metode, dan Tekniknya. Jakarta: PT Raja Grafindo Persada.

Mantja, Lalu. 1984. Sumbawa pada Masa Dulu: Suatu Tinjauan Sejarah. Surabaya: Rint. 
Mbete, Aron Meko. 1990. "Rekontruksi Protobahasa Bali-SasakSumbawa”. Jakarta: Universitas Indonesia (Desertasi Doktor) . 1987. "Cita-cita Penelitian Dialek". Dewan Bahasa: 31,2 .

Poerwadarminta, W.J.S. 1939. Baosastra Djawa. Groninge, Batavia: J.B. Wilters' Uitgevers Maat Schapij N.V.

Sukartha, I Nengah dkk. 1987. "Geografi Dialek Bahasa Sumbawa di Pulau Sumbawa".

Tawangsih Lauder, Multamia R.M. 1990. "Pemetaan dan distribusi Bahasa-bahasa di Tangerang”. Disertasi Doktor. Jakarta: Universitas Indonesia.

Teeuw, A. 1951. Dialek-Atlas van/ of Lombok. Jakarta: Biro Reproduksi Djawatan Tofografi.

Wacana, H.L. 1988. Sejarah Daerah Nusa Tenggara Barat. Proyek Inventarisasi dan Dokumentasi Kebudayaan Nusa Tenggara Barat. 